\title{
Evaluation of Antihypertensive Activity of Aqueous and Ethylic Alcohol Extracts of Stem Bark of Xylopia villosa Chipp (Annonaceae)
}

\author{
Kouame Yao Yves ${ }^{1, *}$, Okpekon Aboua Timothée ${ }^{2}$, Yapi Houphouët Félix ${ }^{1}$ \\ ${ }^{1}$ Laboratory of Pharmacodynamics Biochemical, UFR Biosciences, Felix Houphouet Boigny University, Cote d'Ivoire \\ ${ }^{2}$ Laboratory of Organic Chemistry and Natural Substances, UFR Sciences of Structures of Matter and Technology, Felix Houphouet \\ Boigny University, Cote d'Ivoire
}

Copyright $\bigcirc 2017$ by authors, all rights reserved. Authors agree that this article remains permanently open access under the terms of the Creative Commons Attribution License 4.0 International License

\begin{abstract}
This study aims to evaluate Antihypertensive activity of aqueous and ethanolic extracts of Xylopia villosa stem bark. The induction of hypertension was made with adrenaline on albino rats of wistar strain. Treatments of hypertensive rats with aqueous and ethanolic extracts of Xylopia villosa at doses of 100 and $200 \mathrm{mg} / \mathrm{kg}$ bw and Atenolol (the reference molecule) at doses of 10 and 20 $\mathrm{mg} / \mathrm{kg}$ bw have normalized cardiovascular parameters such as systolic blood pressure, diastolic blood pressure and heart rate. However, these doses all increased the blood concentration of $\mathrm{Na}^{+}$of hypertensive rats. Only treatments with aqueous and ethanolic extracts at a dose of $200 \mathrm{mg} / \mathrm{kg}$ bw were able to bring blood concentration in $\mathrm{K}^{+}$of hypertensive rats to a concentration equivalent to that of normotensive rats.
\end{abstract}

Keywords Xylopia villosa, Adrenaline, Antihypertesive, Systolic Blood Pressure, Diastolic Blood Pressure, Heart Rate

\section{Introduction}

Hypertension is a chronic cardiovascular disease characterized by a rise in blood pressure above normal. It is a serious pathology, called by epidemiologists silent killer [1]. This disease rapidly and considerably alters the quality of life of the patient. It also reduces life expectancy if no effective therapy is undertaken in time. The severity of arterial hypertension is characterized by damage to organs such as the heart, brain, kidney and eye. Hypertension is now seen in most African countries as a real public health problem. Once the disease is declared, the cost of care is prohibitive for developing countries as it can represent up to $60 \%$ of all health care expenditures. With high costs of imported medicines, $80 \%$ of the population who use traditional medicine to meet their primary health care needs [2] find an emergency outlet. The work of Ake-Assi [3] identified 1421 species of medicinal plants in Côte d'Ivoire for the treatment of various pathologies including arterial hypertension.

Xylopia villosa Chipp, a species of this flora is used in traditional medicine in Africa to treat various pathologies including colds and headaches. Its crushed seeds are applied to leg ulcers and boils for healing [4]. Recently, Kouamé and al [5-7] carried out the study of triphytochemistry and acute toxicity, the study of the anti-inflammatory and antioxidant activities of Xylopia villosa Chipp. However, the antihypertensive activity of Xylopia villosa Chipp is not yet known. The objective of this study was to evaluate Xylopia villosa Chipp by evaluating its antihypertensive activity. To achieve this, the specific objectives were to induce hypertension with adrenaline and to determine the effect of extracts of Xylopia villosa Chipp On cardiovascular parameters and electrolyte balance by the determination of sodium and potassium.

\section{Materials and Methods}

\subsection{Plant Material}

Xylopia villosa stems bark were harvested in June 2014 at the National Floristic Center of Felix Houphouët Boigny University where can be found a sample recorded at the number 14712 .

\subsection{Preparation of Extracts}

The stems bark of Xylopia villosa were dried for four weeks in the shade of the sun then made powder using an electric grinder IKAMAG RCT ${ }^{\circledR}$. Hundred (100) grams of powder of Xylopia villosa were macerated for 24 hours in 1 
liter of ethylic alcohol (ethylic alcohol and distilled water mixture: 70/30). The macerated obtained was then filtered twice on white cotton and once on Whatman filter paper $\mathrm{N}^{\circ} 4$. The filtrate obtained in $70 \%$ ethanol was evaporated to dryness at reduced pressure at temperature of $40^{\circ} \mathrm{C}$ using a rotary evaporator type Buchi 161 Water Bath. About aqueous extract preparation, 100 grams of Xylopia villosa stem barks powder were added to 100 milliliters of boiling distilled water. Just like ethanolic preparation, the resulting mixture was filtered twice on white cotton and once on Whatman filter paper $\mathrm{N}^{\circ} 4$. The filtrate obtained is preserved at temperature of $40^{\circ} \mathrm{C}$ in an oven for drying.

\subsection{Determination of Trace Elements in Aqueous and Ethanolic Extracts of Xylopia villosa}

The determination of the trace elements in aqueous and ethylic alcohol extracts of Xylopia villosa was carried out according to the method of Clément and Françoise [8]. The aqueous and ethylic alcohol extracts of Xylopia villosa were dried for 24 hours in a Memmert-Germany oven at $60^{\circ} \mathrm{C}$. Then, they were kept in glass jars.

\subsubsection{Mineralization by Calcination}

For each of the extracts (aqueous and ethylic alcohol) dried in an oven at $60^{\circ} \mathrm{C} .0 .4 \mathrm{~g}$ was weighed using a Sartorius analytic (England) scale in a $30 \mathrm{ml}$ porcelain crucible. This test portion was placed in the Naberthem-Germany muffle furnace set at $550^{\circ} \mathrm{C}$ for 5 hours. After cooling, $2 \mathrm{ml}$ of $0.5 \mathrm{~N}$ chloridic acid were added to the ash obtained and then brought to total evaporation on a sand bath. The recovered final residue was filtered through a $100 \mathrm{~mL}$ volumetric flask and distilled water was added to reach the gauge mark. Five (5) $\mathrm{mL}$ of the filtrate were taken for the determination of the minerals Five (5) $\mathrm{mL}$ of the same filtrate was also removed for the determination of the minerals (Potassium, Iron, Zinc, Magnesium, Copper) by the atomic absorption spectrophotometer AAS 20 type VARIAN, Australia).

\subsubsection{Preparation of the Lanthanum Reagent $\left(\mathrm{La}_{2} \mathrm{O}_{3}\right)$}

Under a hood, a mass of $58.65 \mathrm{~g}$ of $\mathrm{La}_{2} \mathrm{O}_{3}$ was wetted with $50 \mathrm{~mL}$ of distilled water and $250 \mathrm{~mL}$ of concentrated hydrochloric acid was added thereto with slow stirring until the lanthanum was completely diluted. Before any reading, the atomic absorption spectrophotometer was calibrated. To do this, a standard solution of $100 \mathrm{ppm}$ was prepared from a commercial solution called a multi-element of $1000 \mathrm{ppm}$. The preparation was carried out as follows: $2.5 \mathrm{~mL}$ of the stock solution (1000 ppm) was added to a $25 \mathrm{~mL}$ flask and supplemented with concentrated nitric acid to the gauge mark and this solution was used to prepare the standard ranges.

\subsubsection{Preparation of Samples and Standards}

Five (5) $\mathrm{mL}$ of each sample was taken from a $50 \mathrm{~mL}$ vial and $2 \mathrm{~mL}$ of $5 \%$ Lanthanum was added to it before completing with distilled water to the mark. For standards, dilutions from standard solutions of each mineral $(100 \mathrm{mg} / \mathrm{L})$ are performed by supplementing the initial volumes to 50 $\mathrm{mL}$ with distilled water, so as to obtain an accurate concentration range for each mineral. These calibration solutions are then used for the calibration of the flame atomic absorption spectrophotometer. To determine the different quantities of stock solution $(\mathrm{mL})$ to be taken, the following procedure was adopted:

$\mathrm{C}_{\mathrm{i}} \mathrm{V}_{\mathrm{i}}=\mathrm{C}_{\mathrm{f}} \mathrm{V}_{\mathrm{f}}$

With: $\mathrm{C}_{\mathrm{f}}$ : final concentration of the mineral solution (100 ppm)

$\mathrm{C}_{\mathrm{i}}$ : initial concentration of the mineral solution (1 $\mathrm{mg} / \mathrm{mL}$ )

$\mathrm{V}_{\mathrm{i}}$ : initial volume taken (variable) (in $\mathrm{mL}$ )

$\mathrm{V}_{\mathrm{f}}$ : final volume $(\mathrm{mL})$

The wavelengths at which potassium, iron, zinc, magnesium and copper were read were $766.5 \mathrm{~nm} ; 248.3 \mathrm{~nm}$; $258 \mathrm{~nm} ; 285.2 \mathrm{~nm}$ and $324.7 \mathrm{~nm}$ respectively. The results of the optical densities of each mineral made it possible to determine the quantities of minerals (ppm) contained in the aqueous and ethylic alcohol extracts. The mineral contents were determined as follows:

$\mathbf{T}=\left[\left(\mathbf{C}_{\text {ess }}-\mathbf{C}_{\mathrm{wh}}\right) \times \mathbf{V}\right] / \mathbf{P}_{\text {ess }}$

With: $\mathbf{C}_{\text {ess }}$ : concentration of the sample $(\mathrm{mg} / \mathrm{mL})$

$\mathbf{C}_{\mathbf{w h}}$ : white concentration in $\mathrm{mg} / \mathrm{mL}$

$\mathbf{P}_{\text {ess }}$ : test portion $(\mathrm{Kg})$

V: recovery volume of test $(\mathrm{mL})$

T: content of $\mu \mathrm{g} / \mathrm{g}$ or $\mathrm{mg} / \mathrm{Kg}$

\subsection{Reagents, Solvents and Drugs for Antidiabetic Activity}

All products used in this study were provided by Sigma Aldrich Ltd (Paris, France).

\subsection{Experimental Animals}

In this experiment, 60 albino wistar strain rats aged fourteen (14) weeks, mean weight $187.03 \pm 0.06 \mathrm{~g}$ were used. First, a control group of 6 non-hypertensive rats was formed. Secondly, 54 non- hypertensive rats received adrenaline intraperitoneally at a dose of $1 \mathrm{~mL} / \mathrm{kg}$ body weight (bw) during 7 days and the evolution of systolic blood pressure (SBP), diastolic blood pressure (DBP) and heart rate was followed during 7 days (day $\mathrm{D}_{0}$ to $\mathrm{D}_{7}$ ). After the 7 th day, 42 hypertensive rats were selected and divided into 7 groups of 6 rats. Subsequently, a treatment by gavage took place during 6 days with the different drugs according to the following distribution:

- Non-hypertensive control group $\rightarrow 1 \mathrm{~mL}$ of distilled water

- Untreated hypertensive group $\rightarrow 1 \mathrm{~mL}$ of distilled water 
- Hypertensive group treated $\rightarrow 1 \mathrm{~mL}$ of aqueous extract $100 \mathrm{mg} / \mathrm{kg}$ bw

- Hypertensive group treated $\rightarrow 1 \mathrm{~mL}$ of aqueous extract $200 \mathrm{mg} / \mathrm{kg}$ bw

- $\quad$ Hypertensive group treated $\rightarrow 1 \mathrm{~mL}$ of ethylic alcohol extract $100 \mathrm{mg} / \mathrm{kg}$ bw

- $\quad$ Hypertensive group treated $\rightarrow 1 \mathrm{~mL}$ of ethylic alcohol extract $200 \mathrm{mg} / \mathrm{kg}$ bw

- $\quad$ Hypertensive group treated $\rightarrow 1 \mathrm{~mL}$ of Atenolol $^{\circledR} 10$ $\mathrm{mg} / \mathrm{kg}$ bw

- $\quad$ Hypertensive group treated $\rightarrow 1 \mathrm{~mL}$ of Atenolol ${ }^{\circledR} 20$ $\mathrm{mg} / \mathrm{kg} \mathrm{bw}$

\subsubsection{Measurement of Blood Pressure and Heart Rate}

The blood pressure of normal rats and hypertensive rats was recorded by the indirect method using the Visitech BP 2000 recording device. This device simultaneously measures the AP of four rats. It consists of a heated magnetic plate with 2 buttons, a square bottom glass, a temperature control thermometer and a laptop computer with the BP 2000 Blood Pressure analysis version 2004 software allowing to visualize the variations of the pressure Arterial and heart rate.

Before each recording, the caudal vein is dilated by passing the rats in a heating stem for 5 minutes. The rats are then placed in the containment cells and the pressure sensor inserted on the tail. The detected arterial pressure signal emits pressure vibrations that are displayed on the computer monitor as well as the corresponding pressure and heart rate values.

\subsubsection{Blood Determination of Sodium and Potassium in Hypertensive Rats}

Blood was taken from the retro orbital sinus in tubes containing sodium fluoride for the determination of electrolytes (sodium and potassium). Determination of sodium and potassium was carried out using a Hospitex Screen flame spectrophotometer (France).

\subsection{Statistical Analysis}

The values expressed as Mean \pm SEM from 6 animals. The statistical analysis was carried out using one way analysis of variance (ANOVA) followed by Dunnett's test, $\mathrm{P}<0.05$ was considered as significant.

\section{Results}

\subsection{Trace Element Content}

The trace element content (Potassium, Iron, Zinc, Magnesium, Copper) in aqueous and ethylic alcohol extracts of Xylopia villosa are summarized in Table 1.
Table 1. Trace element content in aqueous and ethylic alcohol extracts of Xylopia villosa

\begin{tabular}{|c|c|c|}
\hline \multirow{2}{*}{ Trace element } & \multicolumn{2}{|c|}{ Trace element content $(\mu \mathrm{g} / \mathrm{g}$ of dry extract) } \\
\cline { 2 - 3 } & Aqueous extract & $\begin{array}{c}\text { Ethylic alcohol } \\
\text { extract }\end{array}$ \\
\hline Potassium & $19971,00 \pm 37,02$ & $19128,00 \pm 203,80$ \\
\hline Iron & $16,25 \pm 0,36$ & $10,11 \pm 0,26$ \\
\hline Zinc & $9,34 \pm 0,26$ & $13,74 \pm 0,16$ \\
\hline Magnesium & $1628,00 \pm 14,86$ & $1405,00 \pm 6,56$ \\
\hline Copper & $44,87 \pm 0,15$ & $50,20 \pm 0,25$ \\
\hline
\end{tabular}

\subsection{Induction of Arterial Hypertension by Adrenaline and Evolution of Cardiovascular Parameters}

\subsubsection{Evolution of Systolic Blood Pressure and Diastolic Blood Pressure}

The systolic blood pressure (SBP) and diastolic blood pressure (DBP) of normotensive rats and hypertensive rats are shown in Fig.1. The SBP of all rats prior to adrenaline injection was $121,00 \pm 1.42 \mathrm{~mm} \mathrm{Hg}$ on day D0. After adrenaline injection into the test group, SBP was increased to $124.90 \pm 2.79 ; 133.30 \pm 3.03 ; 155.00 \pm 2.17$ and $176.30 \pm$ $1.60 \mathrm{mmHg}$ on days D2, D4, D6 and D7 respectively.

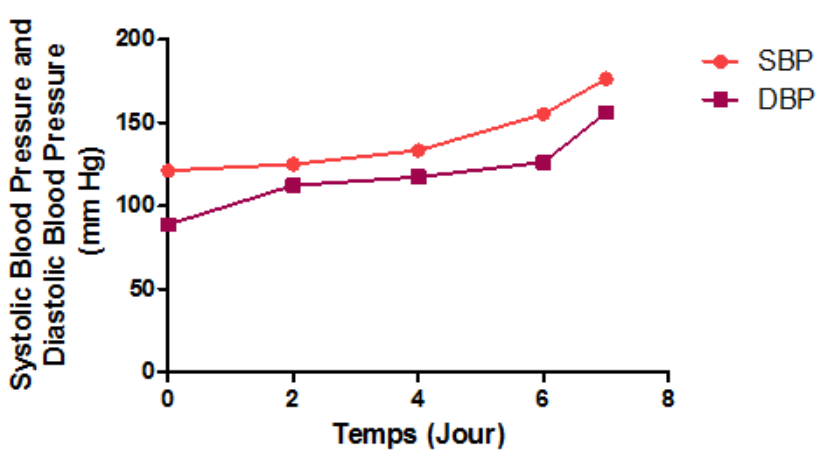

Figure 1. Evolution of SBP and DBP during induction of hypertension by adrenaline

In the case of DBP, before adrenaline injection, it was $88.53 \pm 2.87 \mathrm{~mm} \mathrm{Hg}$ on day D0 in all rats. After injection of adrenaline into the test group, the DBP was increased to $112.20 \pm 3.00 ; 117.30 \pm 0.75 ; 126.00 \pm 1.97$ and $155.90 \pm$ $1.68 \mathrm{mmHg}$ on days D2, D4, D6 and D7 respectively.

\subsection{2: Evolution of Heart Rate}

Changes in heart rate during the induction of arterial hypertension with adrenaline are shown in Fig.2. Prior to the injection of adrenaline, the heart rate (HR) of all rats Was $316.30 \pm 2.60$ beats per minute $(\mathrm{Bt} / \mathrm{min})$ on day D0. After injection of adrenaline into the test group, HR increased to $327.70 \pm 3.07 ; 361.30 \pm 3.10 ; 407.70 \pm 0.88$ and $433.00 \pm$ $3.06 \mathrm{Bt} / \mathrm{min}$ on days $\mathrm{J} 2, \mathrm{~J} 4, \mathrm{~J} 6$ and $\mathrm{J} 7$ respectively. 


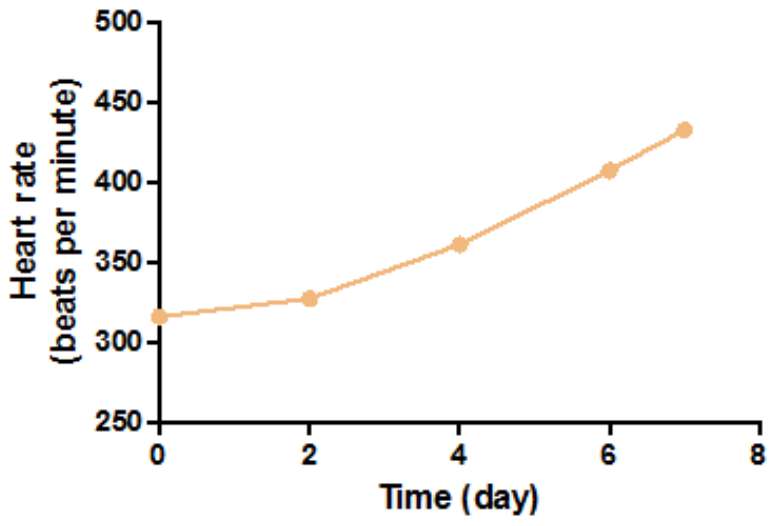

Figure 2. Evolution of heart rate during induction of hypertension by adrenaline

\subsection{Determination of Cardiovascular Parameters after Treatment}

\subsubsection{Determination of Systolic Blood Pressure and} Diastolic Blood Pressure after Treatment

Fig. 3 shows the systolic blood pressure (SBP) and diastolic blood pressure (DBP) of hypertensive rats treated with extracts of Xylopia villosa and Atenolol ${ }^{\circledR}$ (reference molecule).

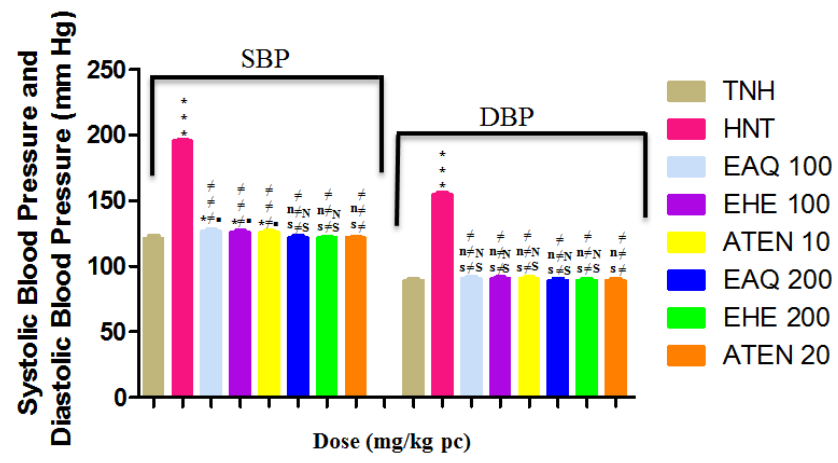

Each histogram represents the mean \pm SEM, $n=6$

$* * * \mathrm{P}<0.001$ : Very highly significant difference from normotensive rats (TNH)

$* \mathrm{P}<0.05$ : Significant difference from normotensive rats $(\mathrm{TNH})$ $\mathrm{P}>$ 0.05: Difference not significant (ns) compared to normotensive rats (TNH)

$\neq \neq \neq \mathrm{P}<0.001$ : very highly significant difference from untreated hypertensive rats $(\mathrm{HNT})$

$\cdot \mathrm{P}<0.05$ : Significant difference from treatment with Atenolol ${ }^{\circledR} 20 \mathrm{mg} / \mathrm{kg}$ bw

$\mathrm{P}>0.05$ : Non-significant difference (NS) compared to treatment with

Atenolol ${ }^{\circ} 20 \mathrm{mg} / \mathrm{kg}$ bw

TNH: Normotensive; HNT: untreated hypertensive

EAQ 100: Aqueous extract $100 \mathrm{mg} / \mathrm{kg}$ bw; EAQ: Aqueous extract 200 $\mathrm{mg} / \mathrm{kg}$ bw

EHE 100: Ethylic alcohol extract $100 \mathrm{mg} / \mathrm{kg}$ bw; EHE 200: Ethylic alcohol extract $200 \mathrm{mg} / \mathrm{kg}$ bw

ATEN 10: Atenolol ${ }^{\circledR} 10 \mathrm{mg} / \mathrm{kg}$ bw; ATEN 20: Atenolol $^{\circledR} 20 \mathrm{mg} / \mathrm{kg}$ bw. bw: Body weight

SBP: Systolic blood pressure; DBP: and diastolic blood pressure

Figure 3. Effects of Atenolol ${ }^{\circledR}$ and aqueous and ethylic alcohol extract extracts of stem bark of Xylopia villosa on SBP and DBP of hypypertensive rats

Prior to the treatment of hypertensive rats with extracts of
Xylopia villosa and Atenolol ${ }^{\circledR}$, the SBP of the normotensive rats was $121.67 \pm 1.29 \mathrm{~mm} \mathrm{Hg}$ while the SBPs of the untreated hypertensive rats group and those to be treated with aqueous extract (100 mg / kg bw), ethylic alcohol extract (100 mg / kg bw), Atenolol ${ }^{\circledR}(10 \mathrm{mg} / \mathrm{kg} \mathrm{bw})$, aqueous extract (200 mg / kg bw), ethylic alcohol extract (200 mg / kg bw) and Atenolol ${ }^{\circledR}(20 \mathrm{mg} / \mathrm{kg} \mathrm{bw})$ were respectively $175.90 \pm 2.89 ; 176.00 \pm 2.31 ; 176.10 \pm 1.73 ; 176.20 \pm 3.46$; $176.70 \pm 1.73 ; 176.80 \pm 2.31$ and $177.20 \pm 1.73 \mathrm{~mm} \mathrm{Hg}$.

After the treatment of hypertensive rats with aqueous extract (100 mg / kg bw), ethylic alcohol extract $(100 \mathrm{mg} / \mathrm{kg}$ bw), Atenolol ${ }^{\circledR}(10 \mathrm{mg} / \mathrm{kg}$ bw), SBPs were respectively $126.67 \pm 1.13 ; 125.69 \pm 1.12 ; 125.67 \pm 1.13$ while SBP of untreated hypertensive rat was $195.77 \pm 0.41 \mathrm{~mm} \mathrm{Hg}$. These SBP increased $(\mathrm{P}<0.05)$ compared to SBP of normotensive rats. However, the SBPs of the hypertensive rats treated with aqueous extract ( $200 \mathrm{mg} / \mathrm{kg} \mathrm{bw})$, ethylic alcohol extract (200 $\mathrm{mg} / \mathrm{kg} \mathrm{bw})$ and Atenolol ${ }^{\circledR}(20 \mathrm{mg} / \mathrm{kg} \mathrm{bw})$ became identical $(\mathrm{P}>0.05)$ to the SBP of the normotensive rats. Furthermore, the SBPs of the hypertensive rats treated with aqueous extract (100 and $200 \mathrm{mg} / \mathrm{kg}$ bw), ethylic alcohol extract (100 and $200 \mathrm{mg} / \mathrm{kg} \mathrm{bw})$ and Atenolol ${ }^{\circledR}(10$ and $20 \mathrm{mg} / \mathrm{kg}$ bw) decreased $(\mathrm{P}<0.05)$ compared to the SBP of untreated hypertensive rats. The effect of Atenolol ${ }^{\circledR}(20 \mathrm{mg} / \mathrm{kg} \mathrm{bw})$ on the SBP of hypertensive rats is similar $(\mathrm{P}>0.05)$ to the effects of the aqueous extract (200 $\mathrm{mg} / \mathrm{kg} \mathrm{bw})$ and ethylic alcohol extract $(200 \mathrm{mg} / \mathrm{kg} \mathrm{bw})$ while it is different $(\mathrm{P}<$ $0.05)$ to the effects of aqueous extract $(100 \mathrm{mg} / \mathrm{kg}$ bw), ethylic alcohol extract $(100 \mathrm{mg} / \mathrm{kg} \mathrm{bw})$ and Atenolol ${ }^{\circledR}(10$ $\mathrm{mg} / \mathrm{kg} \mathrm{pc}$ ).

In the case of DBP, before the treatment of rats rendered hypertensive by Xylopia villosa extracts and Atenolol ${ }^{\circledR}$, the DBP of the normotensive rats was $89.20 \pm 0.97 \mathrm{mmHg}$ Whereas the DBPs of untreated hypertensive rats and those to be treated with aqueous extract $(100 \mathrm{mg} / \mathrm{kg} \mathrm{bw})$, ethylic alcohol extract (100 mg / kg bw), Atenolol ${ }^{\circledR}(10 \mathrm{mg} / \mathrm{kg} \mathrm{bw})$, aqueous extract (200 mg / kg bw), ethylic alcohol extract (200 mg / kg bw) and Atenolol ${ }^{\circledR}(20 \mathrm{mg} / \mathrm{kg} \mathrm{bw})$ were respectively $154.00 \pm 2.89 ; 155.40 \pm 1.73 ; 155.80 \pm 3.46$; $156.10 \pm 2.31 ; 156.70 \pm 1.73 ; 156.90 \pm 2.31$ and $157.00 \pm$ $2.89 \mathrm{mmHg}$.

After the treatment of hypertensive rats with aqueous extract (100 mg / kg bw), ethylic alcohol extract (100 mg / kg bw), Atenolol ${ }^{\circledR}(10 \mathrm{mg} / \mathrm{kg}$ bw), aqueous extract $(200 \mathrm{mg} /$ $\mathrm{kg} \mathrm{bw})$, ethylic alcohol extract ( $200 \mathrm{mg} / \mathrm{kg} \mathrm{bw})$, Atenolol ${ }^{\circledR}$ $(20 \mathrm{mg} / \mathrm{kg} \mathrm{bw})$, the DBPs have respectively bee $90.97 \pm$ $0.75 ; 90.57 \pm 0.57 ; 90.54 \pm 0.75 ; 89.40 \pm 0.68 ; 89.38 \pm 0.68$ and $89.36 \pm 0.68 \mathrm{mmHg}$ Whereas the DBP of untreated hypertensive rats increased to $154.97 \pm 0.98 \mathrm{~mm} \mathrm{Hg}$. DBP in untreated hypertensive rats is increasing $(\mathrm{P}<0.05)$ compared with DBP in normotensive rats whereas DBP Hypertensive rats treated with aqueous extract (100 and $200 \mathrm{mg} / \mathrm{kg} \mathrm{bw}$ ), ethylic alcohol extract (100 and $200 \mathrm{mg} / \mathrm{kg}$ bw) and Atenolol ${ }^{\circledR}(10$ and $20 \mathrm{mg} / \mathrm{kg} \mathrm{bw})$ became identical (P > $0.05)$ than in normotensive rats. In addition, DBPs in hypertensive rats treated with aqueous extract (100 and 200 $\mathrm{mg} / \mathrm{kg} \mathrm{bw}$ ), ethylic alcohol extract (100 and $200 \mathrm{mg} / \mathrm{kg} \mathrm{bw}$ ) 
and Atenolol ${ }^{\circledR}(10$ and $20 \mathrm{mg} / \mathrm{kg}$ bw $)$ are decreasing $(\mathrm{P}<$ $0.05)$ relative to the DBP of untreated hypertensive rats. Also, the effect of Atenolol ${ }^{\circledR}(20 \mathrm{mg} / \mathrm{kg} \mathrm{bw})$ on the DBP of hypertensive rats is equal $(\mathrm{P}>0.05)$ to the effect of the aqueous extract (100 and $200 \mathrm{mg} / \mathrm{kg}$ bw), ethylic alcohol extract (100 and $200 \mathrm{mg} / \mathrm{kg} \mathrm{bw})$ and Atenolol ${ }^{\circledR}(10$ and 20 $\mathrm{mg} / \mathrm{kg} \mathrm{bw})$.

\subsubsection{Determination of Heart Rate after Treatment}

Fig. 4 shows the heart rate (HR) of the hypertensive rats after treatment with the extracts of Xylopia villosa and Atenolol ${ }^{\circledR}$ (reference molecule). The HR of normotensive rats was $316.30 \pm 1.50$ beats per minute (Bat / $\mathrm{min}$ ). The one of untreated hypertensive rats and those to be treated with aqueous extract (100 mg / $\mathrm{kg}$ bw), ethylic alcohol extract (100 mg / kg bw), Atenolol ${ }^{\circledR}(10 \mathrm{mg} / \mathrm{kg} \mathrm{bw})$, aqueous extract (200 mg / kg bw), ethylic alcohol extract $(200 \mathrm{mg} / \mathrm{kg}$ bw) and Atenolol ${ }^{\circledR}(20 \mathrm{mg} / \mathrm{kg}$ bw) were respectively $429.03 \pm 0.78 ; 430.71 \pm 0.82 ; 432.01 \pm 0.66 ; 434.56 \pm 0.63$; $435.03 \pm 0.50 ; 435.11 \pm 0.84$ and $435.69 \pm 0.34 \mathrm{Bat} / \mathrm{min}$.

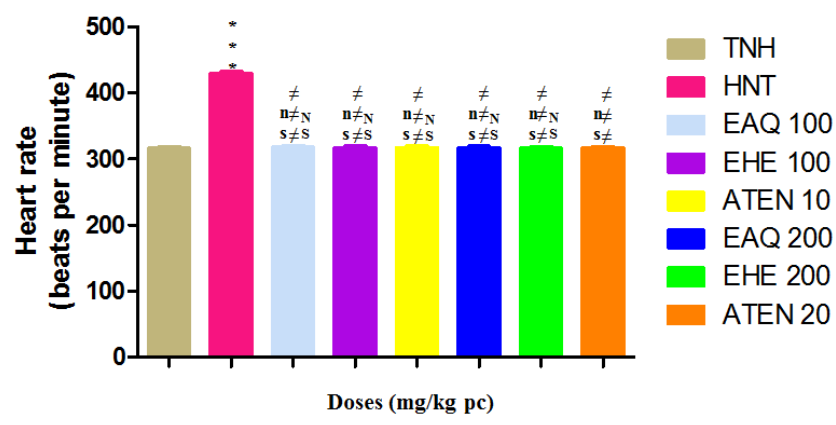

Each histogram represents the mean \pm SEM, $n=6$

$* * * \mathrm{P}<0.001$ : Very highly significant difference from normotensive rats (TNH)

$\mathrm{P}>0.05$ : Difference not significant (ns) compared to normotensive rats (TNH).

$\neq \neq \neq \mathrm{P}<0.001$ : Very highly significant difference from untreated hypertensive rats (HNT)

$\mathrm{P}>0.05$ : Non-significant difference (NS) compared to treatment with Atenolol $\AA 20 \mathrm{mg} / \mathrm{kg}$ bw

TNH: Normotensive; HNT: Untreated hypertensive

EAQ 100: Aqueous extract $100 \mathrm{mg} / \mathrm{kg}$ bw; EAQ: Aqueous extract 200 $\mathrm{mg} / \mathrm{kg}$ bw

EHE 100: Ethylic alcohol extract $100 \mathrm{mg} / \mathrm{kg}$ bw; EHE 200: Ethylic alcohol extract $200 \mathrm{mg} / \mathrm{kg}$ bw

ATEN 10: Atenolol ${ }^{\mathbb{R}} 10 \mathrm{mg} / \mathrm{kg}$ bw ; ATEN 20 : Atenolol $^{\mathbb{R}} 20 \mathrm{mg} / \mathrm{kg}$ bw. bw: Body weight

Figure 4. Effects of Atenolol $\AA$ and aqueous and ethylic alcohol extract extracts of Xylopia villosa stem bark on the heart rate of hypertensive rats

After the treatment of hypertensive rats with aqueous extract (100 mg / kg bw), ethylic alcohol extract $(100 \mathrm{mg} / \mathrm{kg}$ bw), Atenolol ${ }^{\circledR}(10 \mathrm{mg} / \mathrm{kg} \mathrm{bw})$, aqueous extract (200 mg / $\mathrm{kg} \mathrm{bw})$, ethylic alcohol extract (200 mg / $\mathrm{kg} \mathrm{bw})$ and Atenolol ${ }^{\circledR}(20 \mathrm{mg} / \mathrm{kg} \mathrm{bw})$, HR have respectively been $318.37 \pm 1.10 ; 317.73 \pm 1.08 ; 317.64 \pm 1.06 ; 316.91 \pm 1.08$; $316.75 \pm 1.10$ and $316.62 \pm 1.06 \mathrm{Bat} / \mathrm{min}$ while HR of untreated hypertensive rats increased to $430.13 \pm 1.21$ Bat / $\min$. The HR of the hypertensive rats treated with aqueous extract (100 and $200 \mathrm{mg} / \mathrm{kg}$ bw), ethylic alcohol extract (100 and $200 \mathrm{mg} / \mathrm{kg} \mathrm{bw})$ and Atenolol ${ }^{\circledR}(10$ and $20 \mathrm{mg} / \mathrm{kg}$ ) became equal $(\mathrm{P}>0.05)$ to $\mathrm{HR}$ of normotensive rats, whereas
HR of untreated hypertensive rats remained higher $(\mathrm{P}<0.05)$ than this one of normotensive rats. In addition, the HR of hypertensive rats treated with aqueous extract (100 and 200 $\mathrm{mg} / \mathrm{kg} \mathrm{bw}$ ), ethylic alcohol extract (100 and $200 \mathrm{mg} / \mathrm{kg} \mathrm{bw}$ ) and Atenolol ${ }^{\circledR}(10$ and $20 \mathrm{mg} / \mathrm{kg})$ Were decreased $(\mathrm{P}<0.05)$ compared to HR of untreated hypertensive rats. Also, the effect of Atenolol@ $(20 \mathrm{mg} / \mathrm{kg} \mathrm{bw})$ on the heart rate of hypertensive rats is similar $(\mathrm{P}>0.05)$ to the effects of aqueous extract (100 and $200 \mathrm{mg} / \mathrm{kg}$ bw), ethylic alcohol extract (100 and $200 \mathrm{mg} / \mathrm{kg}$ bw) and Atenolol $\mathbb{R}(10 \mathrm{mg} / \mathrm{kg}$ bw).

\subsection{Determination of $\mathrm{Na}^{+}$and $\mathrm{K}^{+}$Electrolytes in Hypertensive Rats}

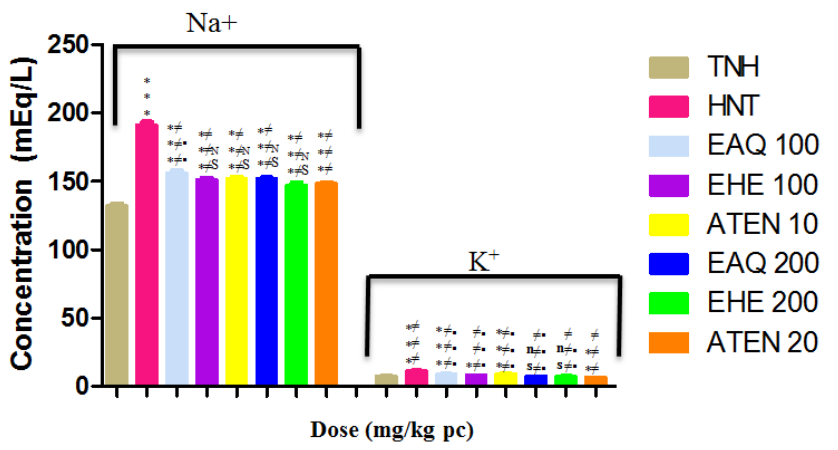

Each histogram represents the mean \pm SEM, $n=6$

$* * * \mathrm{P}<0.001$ : Very highly significant difference from normotensive rats (TNH)

$* * \mathrm{P}<0.01$ : Very significant difference from normotensive rats $(\mathrm{TNH})$ $* \mathrm{P}<0.05$ : Significant difference from normotensive rats $(\mathrm{TNH})$ $\mathrm{P}>0.05$ : Difference not significant (ns) compared to normotensive rats (TNH)

$\not \neq \neq \mathrm{P}<0.001$ : Very highly significant difference from untreated hypertensive rats (HNT)

.. $\mathrm{P}<0.001$ : Very highly significant difference from treatment with Atenolol ${ }^{\circledR} 20 \mathrm{mg} / \mathrm{kg}$ bw

$\omega \mathrm{P}<0.01$ : Very significant difference from treatment with Atenolol ${ }^{\circledR} 20$ $\mathrm{mg} / \mathrm{kg} \mathrm{bw}$

TNH: Normotensive; HNT: Untreated hypertensive

EAQ 100: Aqueous extract $100 \mathrm{mg} / \mathrm{kg}$ bw; EAQ: Aqueous extract 200 $\mathrm{mg} / \mathrm{kg} \mathrm{bw}$

EHE 100: Ethylic alcohol extract $100 \mathrm{mg} / \mathrm{kg}$ bw; EHE 200: Ethylic alcohol extract $200 \mathrm{mg} / \mathrm{kg}$ bw

ATEN 10: Atenolol ${ }^{\circledR} 10 \mathrm{mg} / \mathrm{kg}$ bw ; ATEN 20 : Atenolol $^{\circledR} 20 \mathrm{mg} / \mathrm{kg}$ bw. bw: Body weight

Figure 5. Effects of Atenolol ${ }^{\circledR}$ and aqueous and ethylic alcohol extract extracts of bark stems of Xylopia villosa on the sodium and potassium concentrations of hypertensive rats

Fig. 5 shows the effects of extracts of Xylopia villosa and Atenolol ${ }^{\circledR}$ (reference molecule) on the $\mathrm{Na}+$ and $\mathrm{K}+$ ion concentration of hypertensive rats. The $\mathrm{Na}+$ ion concentration of normotensive rats increased from $132.50 \pm$ $0.89 \mathrm{mEq} / \mathrm{L}$ to $191.40 \pm 1.98 ; 156.10 \pm 1.77 ; 151.60 \pm 0.78$; $152.40 \pm 0.91 ; 152.10 \pm 0.59 ; 147.40 \pm 1.57$ and $148.40 \pm$ $0.65 \mathrm{mEq} / \mathrm{L}$ respectively, in untreated hypertensive rats and those treated with aqueous extract (100 $\mathrm{mg} / \mathrm{kg} \mathrm{bw})$, ethylic alcohol extract (100 mg / kg bw), Atenolol ${ }^{\circledR}(10 \mathrm{mg} / \mathrm{kg} \mathrm{bw})$, aqueous extract (200 mg / kg bw), ethylic alcohol extract $(200 \mathrm{mg} / \mathrm{kg} \mathrm{bw})$ and Atenolol ${ }^{\circledR}(20 \mathrm{mg} / \mathrm{kg} \mathrm{bw})$. All these $\mathrm{Na}+$ ion concentrations remained high $(\mathrm{P}<0.05)$ compared with normotensive rats. Furthermore, the $\mathrm{Na}+$ ion concentrations of hypertensive rats treated with aqueous extract (100 and $200 \mathrm{mg} / \mathrm{kg} \mathrm{bw}$ ), ethylic alcohol extract 
(100 and $200 \mathrm{mg} / \mathrm{kg}$ bw) and Atenolol ${ }^{(}(10$ and $20 \mathrm{mg} / \mathrm{Kg}$ bw) decreased relative to $\mathrm{Na}+$ ion concentration in untreated hypertensive rats. The effect of Atenolol ${ }^{\circledR}(20 \mathrm{mg} / \mathrm{kg} \mathrm{bw})$ on the $\mathrm{Na}+$ ion concentration of hypertensive rats is similar $(\mathrm{P}>0.05)$ to the effects of aqueous extract $(200 \mathrm{mg} / \mathrm{kg} \mathrm{bw})$ ethylic alcohol extract (100 and $200 \mathrm{mg} / \mathrm{kg} \mathrm{bw})$ and Atenolol ${ }^{\circledR}(100 \mathrm{mg} / \mathrm{kg} \mathrm{bw})$ whereas it is different $(\mathrm{P}<0.05)$ to this one of the aqueous extract (100 mg / $\mathrm{kg} \mathrm{bw}$ ).

Regarding the $\mathrm{K}+$ ion concentration, it increased from $7.57 \pm 0.28 \mathrm{mEq} / \mathrm{L}$ in normotensive rats to $11.30 \pm 0.09$; $8.90 \pm 0.16 ; 8.15 \pm 0.03$ and $9.19 \pm 0.03 \mathrm{mEq} / \mathrm{L}$ respectively, in untreated hypertensive rats and those treated with aqueous extract (100 mg / kg bw), ethylic alcohol extract $(100 \mathrm{mg} / \mathrm{kg}$ bw) and Atenolol ${ }^{\circledR}(10 \mathrm{mg} / \mathrm{kg} \mathrm{bw})$. These concentrations are increasing $(\mathrm{P}<0.05)$ compared to normotensive rats. Treatment with Atenolol $\AA$ ( $20 \mathrm{mg} / \mathrm{kg} \mathrm{bw}), \mathrm{K}+$ ion concentration $(6.78 \pm 0.00 \mathrm{mEq} / \mathrm{L})$ of hypertensive rats decreased $(\mathrm{P}<0.05)$ compared to this one of normotensive rats $(7.57 \pm 0.28 \mathrm{mEq} / \mathrm{L})$. However, the $\mathrm{K}+$ concentration of hypertensive rats treated with aqueous and ethylic alcohol extracts at $200 \mathrm{mg} / \mathrm{kg}$ bw remained similar $(\mathrm{P}>0.05)$ to that of normotensive rats. The $\mathrm{K}+$ ion concentrations of hypertensive rats treated with aqueous extract (100 and 200 $\mathrm{mg} / \mathrm{kg} \mathrm{bw}$ ), ethylic alcohol extract (100 and $200 \mathrm{mg} / \mathrm{kg} \mathrm{bw})$ and Atenolol ${ }^{\circledR}(10$ and $20 \mathrm{mg} / \mathrm{kg}$ bw) decreased $(\mathrm{P}<0.05)$ compared to the $\mathrm{K}+$ concentration of untreated hypertensive rats. The effect of Atenolol ${ }^{\circledR}(20 \mathrm{mg} / \mathrm{kg} \mathrm{bw})$ on the $\mathrm{K}+$ ion concentration of hypertensive rats differs $(\mathrm{P}<0.05)$ from those of the aqueous extract ( 100 and $200 \mathrm{mg} / \mathrm{kg} \mathrm{bw}$ ), ethylic alcohol extract (100 and $200 \mathrm{mg} / \mathrm{kg} \mathrm{bw}$ ) and Atenolol $\mathbb{(}(10 \mathrm{mg} / \mathrm{kg} \mathrm{bw})$.

\section{Discussion}

Concerning the antihypertensive activity of aqueous and ethanolic extracts of the stem bark of Xylopia villosa, it was investigated on systolic blood pressure (SBP), diastolic blood pressure (DBP) and heart rate (HR) after induction of arterial hypertension by adrenaline. The results of the study showed that extracts of Xylopia villosa resulted in a significant reduction in adrenaline-induced hypertension by normalizing the cardiovascular parameters (SBP, DBP and HR) of hypertensive rats. This suggests that the aqueous and ethanolic extracts of the stem bark of Xylopia villosa contain antihypertensive compounds. These results are in agreement with those of N'Go [10], Tiékpa et al [11] which showed that the treatment of hypertensive rats with the aqueous extract of Terminalia superba Englers \& Diels (Combretaceae) and Wakouba Salt extracted from Elaeis guineensis normalized the cardiovascular parameters of said rats. The antihypertensive effects of Xylopia villosa extracts also resemble those of the extracts of Stephania tetranda (Menispermaceae) $\mathbf{Y u}$ et al [12] and Berberis vulgaris (Berberidaceae) Fatehi-Hassanabab et al [13].

The determination of the trace elements revealed the presence of magnesium and potassium in the aqueous and ethanolic extracts of Xylopia villosa. This decrease in blood pressure after administration of extracts of Xylopia villosa could be explained by the presence of these two trace elements. Indeed, studies by Kass et al [14] showed that magnesium supplementation in hypertensive patients led to a modest decrease in blood pressure. Thus, Whelton et al [15], Tunstall-Pedoe [16] and Geleijnse [17] showed that a potassium-rich diet lowered systolic and diastolic pressures and led to decreased cardiovascular events and even mortality. This hypotensive effect could militate for the use of Xylopia villosa in the treatment of hypertension.

Concerning the $\mathrm{Na}^{+}$and $\mathrm{K}^{+}$electrolytes of hypertensive rats, there was a significant increase in $\mathrm{Na}+$ concentration in untreated hypertensive rats and those treated with extracts of Xylopia villosa and Atenolol. Nevertheless, the concentration of $\mathrm{K}^{+}$ion has had three phases. A first phase in which it increased in untreated hypertensive rats and those treated with Atenolol $(10 \mathrm{mg} / \mathrm{kg} \mathrm{bw})$ and aqueous and ethanolic extracts at a dose of $100 \mathrm{mg} / \mathrm{kg}$ bw. A second phase in which Atenolol $(20 \mathrm{mg} / \mathrm{kg} \mathrm{bw})$ resulted in a decrease in $\mathrm{K}^{+}$ion concentration compared to normotensive control rats. Finally, a third phase in which aqueous and ethanolic extracts at a dose of $200 \mathrm{mg} / \mathrm{kg}$ bw reduced the concentration of $\mathrm{K}^{+}$ion similar to that of normotensive control rats. Indeed, the ability of the kidneys to excrete or conserve sodium is a key factor in the regulation of blood pressure. Most studies show that reduced salt intake reduces blood pressure. On the other hand, the increase in potassium intake makes it possible to lower the blood pressure, a phenomenon which could be explained by the potassium's ability to increase the excretion of sodium and by its vasoactive effects on the blood vessels [18]. The $\mathrm{Na}+$ and $\mathrm{K}$ + ion concentrations obtained are consistent with the distribution of sodium and potassium in the body. Indeed, the distribution of sodium and potassium in the body is one of the conditions of cell life, especially for nerve and muscle function. There is about 15 times more sodium in the blood than in the cell and there are about 28 times more potassium in the cell than in the blood [19]. To bring nutrients to different cells, a mechanism, using sodium, among others, allows cells to let in what they need to function. Once in the cell, sodium has done its job and must come out because if the cell remained swollen in sodium and water, it could no longer function. A mechanism then allows the sodium to leave the cell, but it requires the presence of potassium to replace it thanks to an ingenious system of "pumps". Sodium and potassium form a necessary tandem for the correct regulation of blood pressure [19].

\section{Conclusions}

The results of the studies showed that aqueous and ethanolic extract of Xylopia villosa resulted in a significant reduction in adrenaline-induce hypertension by normalizing 
the cardiovascular parameters (SBP, DBP and HR) of hypertensive rats. This suggests that aqueous and ethanolic extracts of stem bark of Xylopia villosa contain antihypertensive compounds. Treatment of hypertensive rats with different drugs resulted in an increase in the concentration of $\mathrm{Na}^{+}$ions compared to normotensive rats. However, the aqueous and ethanolic extracts of Xylopia villosa at a dose of $200 \mathrm{mg} / \mathrm{kg}$ bw resulted in a concentration of $\mathrm{K}^{+}$ion similar to normotensive rats.

\section{Ethical Approval}

The experimental procedures and protocols used in this study were approved by the Ethical Committee of Health Sciences, University Félix Houphouet-Boigny. These guidelines were in accordance with the European Council Legislation 87/607/EEC for the protection of experimental animals. All efforts were made to minimize animal suffering and reduce the number of animals used.

\section{REFERENCES}

[1] Jean-Louis C., Jacques G. Hypertension artérielle essentielle et système nerveux adrénergique, édition Sandoz: édité par PIL-12, av. Victor Hugo 75016, Paris, 1982, 127p

[2] N.R. A.OlAYiWOLA, S. B. AUDREY, D. S. DJAJA, G. ZHENGANG. Place des plantes médicinales dans la thérapeutique. Bull. O.M.S. 64: 159-75, 1986.

[3] L. Ake-Assi. Rapport sur le colloque international sur la médecine traditionnelle et pharmacopée africaine à Abidjan, Côte d'Ivoire, Bull. Med. Trad. Pharm. 4: 203; 1991.

[4] H.M. Burkill. The useful plants of west tropical Africa. Editions Royal Botanic Gardens, Kew, 960p, 1985.

[5] Y.Y. Kouame, A.T. Okpekon, H.F. Yapi, K.G. Gbassi, Y.J. Assi, Y.K.F Kouakou. Phytochemical screening and acute toxicity study of Xylopia villosa (annonaceae) barks stems of aqueous and hydroethanolic extracts. European Journal of Pharmaceutical and Medical Research 3(6), 526-531, 2016.

[6] Y.Y. Kouame, A.T. Okpekon, H.F. Yapi, K.G. Gbassi. Evaluation of Anti-Inflammatory Activities of Aqueous and Ethanolic Extracts of Xylopia villosa (Annonaceae). Asian Journal of Biochemical and Pharmaceutical Research Issue 3 (Vol. 6), 2231-2560, 2016.
[7] Y.Y. Kouame, A.T. Okpekon, G.L. Niamketchi, K.G. Gbassi, H.F. Yapi. Evaluation of antioxidant activity of aqueous and ethanolic extracts of stem bark of xylopia villosa chipp (annonaceae). International Journal of Biochemistry and Biophysics 4(3): 25-30, 2016.

[8] M. Clement, P. Francoise. Analyse chimique des sols. Édition Tec et Doc, 387 p, 2003.

[9] OVF, Office Veterinaire Federal, 1981, No. 800.116-1.04.

[10] Ngo L. T. E., 2011. Effets antihypertenseurs des extraits de Terminalia superba Englers \& Diels (Combretaceae): étude in vivo et in vitro. Thèse de doctorat unique. Université de Franche-Comté (France). 155p.

[11] Tiekpa W. J., Koutou A., Bahi C., N'guessan J.D. \& Coulibaly A., 2014. - Evaluation of the effect of "wakouba" on the lipid profile, systolic blood pressure (sbp) diastolic $(\mathrm{dbp})$ and blood glucose in hypertensive rabbits. IJABPT, 5(4): 87-95.

[12] Yu X. C., Wu S., Chen C. F., Pang K. T. \& Wong T. M. 2004. Antihypertensive and anti-arrhytmic effects of an extract of Radix Stephaniae tetrandae in the rat. J pharm pharmacol., 56: 115-122.

[13] Fatehi-Hassanabab Z., Jafarzade M., Tarhini A. \& Fatehi M. 2005. The antihypertensive and vasodilatory effects of aqueous extract from Berberis vulgaris fruit on hypertensive rats. Phytother. Res. 19: 222-225.

[14] Kass L., Weekes J. \& Carpenter L. 2012. Effect of magnesium supplementation on blood pressure: a meta-analysis. Eur J Clin Nutr. 66 (4): 411-8.

[15] Whelton P. K., He J., Cutler J. A., Brancati F. L., Appel L. J., Follmann D. \& Klag M. J. 1997. Effects of oral potassium on blood pressure. Meta-analysis of randomized controlled clinical trials. JAMA. 277 (20): 1624-32.

[16] Tunstall-Pedoe H. 1999. Does dietary potassium lower blood pressure and protect against coronary heart disease and death? Findings from the Scottish heart health study? Semin Nephrol; 19: $500-2$.

[17] Geleijnse J. M., Kok F. J. \& Grobbee D. 2003. Blood pressure response to changes in sodium and potassium intake: A metaregression analysis of randomised trials. J Hum Hypertens; 17: 471-80.

[18] European Food Information Council. Salt, potassium and blood pressure control. Accessible on: http://www.eufic.org/ article/fr/nutrition/sel/artid/sel-potassium-pression-arterielle/ Accessed December 24, 2016.

[19] T. Souccar: Sodium et Potassium: leur rôle dans l'hypertension. Santé cardiovasculair e http://www.thierrysouccar.com/sante/info/sodium-et-potassi um-leur-role-dans-lhypertension-750. Consulté le 23/01/2017 